Journal of Maternal and Child Health (2017), 2(3): 246-257

https://doi.org/10.26911/thejmch.2017.02.03.06

\title{
Biopsychosocial Factors, Life Course Perspective,and Their Influences on Language Development in Children
}

\author{
Latifah Safriana1,2), Harsono Salimo3), Yulia Lanti Retno Dewi4) \\ 1) School of Health Polytechnics Permata Indonesia, Yogyakarta \\ ${ }^{2)}$ Masters Program in Public Health, Universitas Sebelas Maret \\ 3)Department of Pediatrics, Dr. Moewardi Hospital, Surakarta \\ 4)Department of Nutrition, Faculty of Medicine, Universitas Sebelas Maret
}

\begin{abstract}
Background: Speech and language disorder if untreated may cause deficiency in reading, verbal, psychosocial, behavioral, and academic abilities. Studies have shown that birthweight, body length at birth, maternal education, parenting style, maternal stress, incomeat pregnancy, and current income can influence child development. This study aimed to determinethe biopsychosocial factors, life course perspective, and their influences on language development in children.

Subject and Method: This was an analytic observational study using case control design.The study was conducted in Surakarta, Central Java, from February to May 2017. A sample of 140 children aged 2 to 5 years old were selected for this study by fixed disease sampling with 1:3 ratio between case (children with speech and language disorder) and control (children without such disorder). The dependent variable was child speech and language development. The independent variables were birth weight, body length at birth, maternal education, maternal stress, parenting style, family income at pregnancy, and current family income. The data were collected by a set of questionnaireand medical record. The data on speech and language ability was measured by Denver II questionnaire. Path analysis was employed for data analysis.

Results: Language developmentwas directly and positively affected by democratic parenting style $(b=0.46 ; \mathrm{SE}=0.08 ; \mathrm{p}<0.001)$, permissive parenting style $(\mathrm{b}=0.10 ; \mathrm{SE}=0.11 ; \mathrm{p}=0.020)$, birthweight $(b=0.12 ; \mathrm{SE}=0.02 ; \mathrm{p}=0.002)$, maternal education $(\mathrm{b}=0.11 ; \mathrm{SE}=0.31 ; \mathrm{p}=0.007)$, maternal stress $(b=-0.13 ; \mathrm{SE}=0.04 ; \mathrm{p}=0.013)$. Language development directly and negatively affected by authoritarian parenting style $(\mathrm{b}=-0.37 ; \mathrm{SE}=0.09 ; \mathrm{p}<0.001)$. Language development was indirectly affected by body length at birth, family income at pregnancy, and current family income.

Conclusion: Language developmentis directly affected by parenting style, birthweight, maternal education, maternal stress.
\end{abstract}

Keywords: biopsychosocial, life course,language development,children2 to 5 years old, path analysis

\section{Correspondence:}

Latifah Safriana. School of Health Polytechnics Permata Indonesia, Yogyakarta. Email: latifsafri@gmail.com. Mobile: +6282225246917.

\section{BACKGROUND}

Language development involves cognitive, sensory motor, psychological emotion, and the surrounding environment. Language disorder will cause reading disorder, verbal, psychosocial adjustments, behavior, and academic abilities. Language acquisition requires the interaction of biological systems and complex behaviors and learning, combined with responsive environmental stimuli (Mueller, 2016).

Language development disorder is the inability or limited ability to use linguistic symbols to communicate verbally.

This disorder occurs in the development phase of children under three years who are learning to speak and to use language (Hidajati, 2009). Language and speech disorder can be observed in 3 years old and 
their conversation is difficult to understand (Soetjiningsih, 2012). The prevalence of speech and language disorder is between $1 \%$ and $32 \%$ (Busari, 2004). Speech disorder in the form of language delay with expressive vocabulary that lack or no word combination occur in $15 \%$ of children aged 24-29 months (Buschman, 2008; Mcleod, 2009).

Maternal education has a role in child development because education can create a positive attitude for mothers so that they can stimulate language development in preschool age, especially children less than 3 years old (Hidayat, 2005). Children with a low socio-economic history have a higher developmental disorder than children with a high socioeconomic history (Soetjiningsih, 2012).

Children who are raised by permissive parents tend to lose their sense of responsibility, poor emotional control, poor performance. Children who are raised from democratic parents have better personal and social adjustment so that children have the opportunity to optimize their development. Democratic parents can provide a comfortable environment for children so that it will affect the development of better language (Hurlock, 1978). Body length at birth affects the body size of the baby which then affects the birth weight of the baby (Morgan et al., 2016). Low birth weight can affect child development slower than normal weight babies (Hurlock, 1978, Verkasalo et al., 2004).

Smith et al., (2011) stated that stress in parents can affect children's speech. Parents with mild stress who teach children to talk have a positive impact on children's language development.

Given the many factors that are thought to influence children's development, studies on biopsychosocial factors and a lifelong perspective as well as their influence on language development in children 2 to 5 years are needed.

\section{SUBJECT AND METHOD \\ 1. Design of the Study}

This was observational analytic study with control case study design (control case study). The study was conducted at Regional Public Hospital Dr. Moewardi, Surakarta and the Integrated Islamic Early Childhood Education of Nur Hidayah, Aisyiyah, Baitul Ilmi, and Umm Salamah in Surakarta.

\section{Population and Sample}

The population of this study was children aged 2 to 5 years in Surakarta. The samples in this study were 140 subjects using fix disease sampling technique.

\section{Variables of the Study}

There were 9 variables in this study which consisted of dependent and independent variables. The dependent variable was child language development. The independent variables were birth weight, birth length, maternal education, family income at pregnancy, current family income, authoritarian parenting, permissive upbringing, democratic parenting, and maternal stress.

\section{Operational Definition of Variables} Birth weight was the baby's weight that measured immediately after the baby was born. Body length at birth was the length of the baby's body right after the baby was born. Maternal education was the last formal education taken by mothers of study subjects. Family income at pregnancy was income earned by parents of the study subjects during pregnancy. Current income was income earned by parents of study subjects in the last 1 month.

Stress was a condition that suppressed a person's psychological state in reaching an opportunity. Parenting was the application of the mother's way of educating and nurturing children. Language 
development was the ability of receptive and expressive language in children.

\section{Instruments of the Study}

Data collection used were Denver II, questionnaires (covering data on mother and child identity, maternal education, income, maternal parenting, maternal stress), medical records (including child names, date of birth, and Denver II test results sheets), $\mathrm{MCH}$ books (including birth weight, birth length) and student documents from Early Childhood Education (name and date of birth).

Based on the results of the reliability test that had been done, the measurement results for the parenting instrument obtained Cronbach alpha value 0.98 , so that all items from the parenting instrument question were declared reliable.

\section{Data Analysis}

Quantitative data analysis was done univariately to display data on subject characteristics and description of study variables.

\section{Table 1. Characteristics of Study Subject}

\begin{tabular}{llcc}
\hline \multicolumn{1}{c}{ Characteristics } & \multicolumn{1}{c}{ Criteria } & \multicolumn{2}{c}{ Language Development } \\
\cline { 3 - 4 } Child age (years) & 2 years & 31 & \% \\
& 3 years & 35 & 22.14 \\
& 4 years & 54 & 25.00 \\
Maternal Age & 5 years & 20 & 38.57 \\
& Elementary School & 18 & 14.29 \\
& Junior High School & 17 & 12.86 \\
Maternal & Senior High School & 48 & 12.14 \\
Occupation & University & 57 & 34.29 \\
& Private employee & 64 & 40.71 \\
& Entepreneur & 54 & 45.71 \\
& Civil Servant & 11 & 38.57 \\
\hline
\end{tabular}

\section{Univariate analysis}

Univariate analysis was applied to display the subject characteristics data and description of the study variables. Table 2 showed that each variable had a relatively small diversity of data. The mean described the average value while the SD (standard deviation) described how far the data
Bivariate analysis analyzed the effect of exogenous variables on endogenous variables using the Pearson product moment test. Multivariate analysis with path analysis used AMOS 22 to analyze the effect of exogenous variables on endogenous variables through intermediate variables and to know the exogenous direct and indirect effects on endogenous

\section{RESULTS}

\section{Characteristics of Study Subject}

Table 1 showed that the study subjects were 54 study subjects (38.57\%) who were 4 years of age. The majority of maternal education at the college level is 57 study subjects (40.71\%). Most mothers work in the private sector as many as 64 study subjects (45.71\%). varies. The minimum value described the smallest data value and the maximum represented the largest value in the data. A small SD value was an indication of representative data. The highest $\mathrm{SD}$ value was birth weight variable with units of grams per 100 was 5.49 and the smallest SD in permissive parenting was 1.29. 
Table 2. Univariate analysis of study variables

\begin{tabular}{lccccc}
\hline \multicolumn{1}{c}{ Variable } & N & Mean & SD & Min. & Max. \\
\hline Birth weight (x 100 g) & 140 & 30.13 & 5.49 & 12 & 41 \\
Body length at birth (cm) & 140 & 48.89 & 2.23 & 40 & 58 \\
Family income at pregnancy (x Rp 100,000) & 140 & 15.51 & 4.49 & 8 & 20 \\
Current family income (x Rp 100,000) & 140 & 16.50 & 4.16 & 8 & 20 \\
Maternal stress & 140 & 22.03 & 4.57 & 12 & 38 \\
Authoritarian parenting & 140 & 4.91 & 2.39 & 1 & 9 \\
Permissive parenting & 140 & 3.54 & 1.29 & 1 & 7 \\
Democratic parenting & 140 & 6.87 & 2.60 & 1 & 10
\end{tabular}

Table 3. Bivariate analysis of factors that influence language development

\begin{tabular}{lcr}
\hline \multicolumn{1}{c}{ Independent Variable } & \multicolumn{2}{c}{ Language Development } \\
\cline { 2 - 3 } & $\mathbf{r}$ & $\mathbf{p}$ \\
\hline Birth weight (gram per 100) & 0.26 & 0.002 \\
Body length at birth (cm) & 0.28 & 0.001 \\
Maternal education & 0.41 & $<0.001$ \\
Family income at pregnancy (per 100.000) & 0.21 & 0.011 \\
Current family income (per 100.000) & 0.31 & $<0.001$ \\
Authoritarian parenting & -0.80 & $<0.001$ \\
Permissive parenting & -0.26 & 0.002 \\
Democratic parenting & 0.83 & $<0.001$ \\
Maternal stress & -0.64 & $<0.001$ \\
\hline
\end{tabular}

\section{Bivariate analysis}

Table 3 showed the bivariate analysis of factors that influence language development consisting of birth weight, birth length, maternal education, family income at pregnancy, current family income, authoritarian parenting, permissive parenting, democratic parenting, and maternal stress.

Bivariate analysis showed that birth weight $(r=0.26, p=0.002)$, body length at birth ( $\mathrm{r}=0.28, \mathrm{p}=0.001)$, maternal education ( $\mathrm{r}=0.41, \mathrm{p}<0.001)$, family income at pregnancy $(\mathrm{r}=0.21, \mathrm{p}=0.011)$, current family income $(\mathrm{r}=0.31, \mathrm{p}<0.001)$, and democratic parenting $(\mathrm{r}=0.83, \mathrm{p}<0.001)$ had a positive influence on language development in children and was statistically significant.

Authoritarian parenting $(\mathrm{r}=0.80, \mathrm{p}$ $<0.001)$, permissive parenting $(r=0.26, p=$
0.002), and maternal stress $(\mathrm{r}=0.64, \mathrm{p}$ $<0.001)$ had a negative influence on language development in children and was statistically significant.

\section{Path Analysis}

Structural models were estimated using IBM SPSS AMOS 22 to analyze the effect of exogenous variables on endogenous variables through intermediate variables and to know the exogenous direct and indirect effects on endogenous.

Indicators that indicated the suitability of the path analysis model in Table 4 showed the presence of a goodness of fit measure (measurement of model fit) and the fit index (match index) obtained CMIN $=1.32 \mathrm{p}=0.139(>0.05), \mathrm{NFI}=0.96(>$ 0.90), CFI $=0.99(>0.90)$, and RMSEA $=$ $0.05(<0.08)$. 


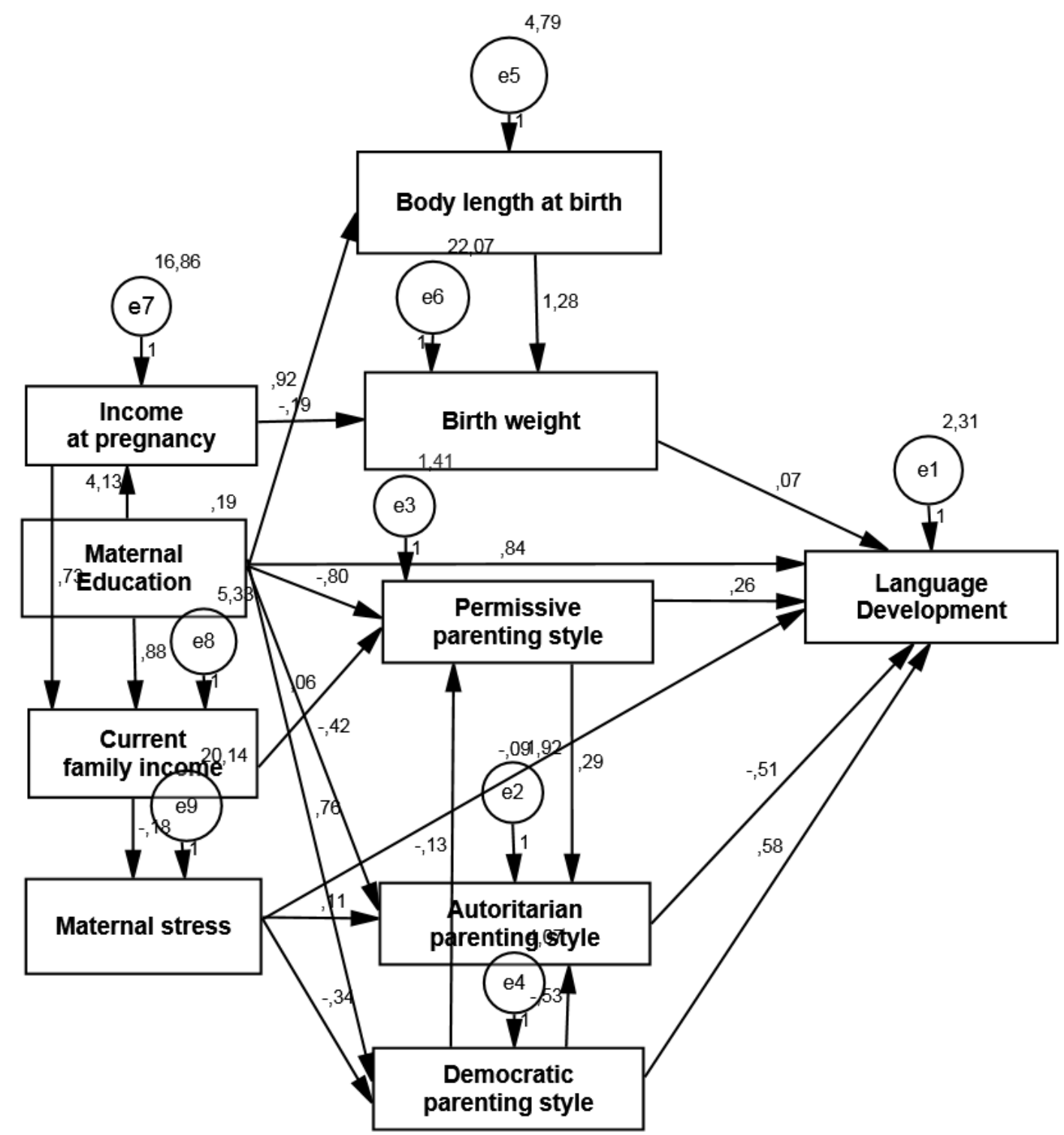

Figure 1. Structural Model of Path Analysis

The results of estimation obtained values as in Figure 1 which showed the variables causal effect relationship indicated by variable coefficients on each path. The path coefficient showed the relationship of the independent and dependent variables in the original measurement unit.

Language development was directly influenced by democratic parenting, birth weight, authoritarian parenting, maternal education, permissive parenting, and maternal stress. Language development was indirectly influenced by family income at pregnancy, current family income, and birth length.

Democratic parenting would improve language development by 0.46 units $(\mathrm{b}=$ $0.46 ; \mathrm{SE}=0.08 ; \mathrm{p}<0.001$ )

Each unit increase of birth weight would increase language development by 0.12 units $(b=0.12 ; \mathrm{SE}=0.02 ; \mathrm{p}=0.002)$.

Each unit increase of authoritarian parenting would reduce language development by 0.37 units $(b=-0.37 ; \mathrm{SE}=0.09 ; \mathrm{p}$ $<0.001)$. 
Safriana et al./ Biopsychosocial Factors, Life Course Perspective, and Their

Table 4. The result of path analysis of the independent variables toward language development

Endogenous

Variables

Direct influence

Language development

Language development

Language development

Language development

Language development

Language development

Indirect influence

Family income at

pregnancy

(x Rp 100,000)

Current family income

(x Rp 100,000)

Current family income (x

Rp 100,000)

Maternal stress

Democratic parenting

Democratic parenting

Permissive parenting

Permissive parenting

Birth length

Permissive parenting

Birth weight

(g per 100)

Birth weight

(g per 100)

Authoritarian parenting

Authoritarian parenting

Authoritarian parenting

Authoritarian parenting

$\leftarrow$ Democratic

$\leftarrow$ Birth weight (x 100 g)

$\leftarrow$ Authoritarian parenting

$\leftarrow$ Maternal stress

$\leftarrow$ Permissive parenting

$\leftarrow$ Maternal stress

$\leftarrow$ Maternal education

$\leftarrow$ Maternal education

$\leftarrow$ Family income at pregnancy

(x Rp 100,000)

$\leftarrow$ Current family income $(x \mathrm{Rp}$

$$
\text { 100,000) }
$$

$\leftarrow$ Maternal stress

$\leftarrow$ Maternal education

$\leftarrow$ Maternal education

$\leftarrow$ Current family income

$\leftarrow$ (x Rp 100,000)

$\leftarrow$ Maternal stress

$\leftarrow$ Democratic parenting

$\leftarrow$ Body length at birth $(\mathrm{cm})$

$\leftarrow$ Family income at pregnancy

(per 100.000)

$\leftarrow$ Maternal stress

$\leftarrow$ Maternal education

$\leftarrow$ Permissive parenting

$\leftarrow$ Democratic parenting

Fit Model

CMIN $=1.32 \mathrm{p}=0.139(\geq 0.05)$

$\mathrm{NFI}=0.96(\geq 0.90)$

CFI $=0.99(\geq 0.90)$

RMSE $=0.05(\leq 0.08)$

A ${ }^{*}$ : non-standardized path coefficient

Each unit increase of maternal education would improve language development by 0.11 units $(b=0.11 ; \mathrm{SE}=0.31 ; \mathrm{p}=$ 0.007).

Each unit increase of permissive parenting would improve language development by 0.10 units $(\mathrm{b}=0.10 ; \mathrm{SE}=0.11 ; \mathrm{p}=$ o.020)

$\begin{array}{llll}\mathbf{b}^{*} & \text { SE } & \mathbf{p} & \boldsymbol{\beta}^{* *}\end{array}$

$\begin{array}{rrrr}0.46 & 0.08 & <0.001 & 0.58 \\ 0.12 & 0.02 & 0.002 & 0.07 \\ -0.37 & 0.09 & <0.001 & -0.51 \\ 0.11 & 0.31 & 0.007 & 0.85 \\ 0.10 & 0.11 & 0.020 & 0.26 \\ -0.13 & 0.04 & 0.013 & -0.09\end{array}$

$\begin{array}{llll}0.39 & 0.80 & <0.001 \quad 4.13\end{array}$

$\begin{array}{llll}0.09 & 0.49 & 0.076 & 0.88\end{array}$

$\begin{array}{llll}0.79 & 0.05 & <0.001 & 0.73\end{array}$

$\begin{array}{llll}-0.17 & 0.09 & 0.047 & -0.18\end{array}$

$\begin{array}{llll}-0.59 & 0.05 & <0.001 & -0.34\end{array}$

$\begin{array}{llll}0.13 & 0.39 & 0.054 & 0.76\end{array}$

$\begin{array}{llll}-0.27 & 0.26 & 0.002 & -0.80\end{array}$

$\begin{array}{llll}0.20 & 0.03 & 0.018 & 0.06\end{array}$

$\begin{array}{llll}0.18 & 0.43 & 0.031 & 0.92\end{array}$

$\begin{array}{llll}-0.27 & 0.04 & <0.001 & -0.13\end{array}$

$\begin{array}{llll}0.51 & 0.18 & <0.001 & 10.3\end{array}$

$\begin{array}{llll}-0.15 & 0.09 & 0.034 & -0.19\end{array}$

$\begin{array}{llll}0.21 & 0.03 & <0.001 & 0.11\end{array}$

$\begin{array}{llll}-0.08 & 0.28 & 0.136 & -0.42\end{array}$

$\begin{array}{llll}0.16 & 0.09 & 0.003 & 0.29\end{array}$

$\begin{array}{llll}-0.58 & 0.06 & <0.001 & -0.53\end{array}$
**: standardized path coefficient

Each unit increase of maternal stress would reduce language development by 0.13 units $(\mathrm{b}=0.13 ; \mathrm{SE}=0.04 ; \mathrm{p}=0.013)$.

Each unit increase of maternal education would increase maternity income by 0.39 units $(b=0.39 ; \mathrm{SE}=0.80 ; \mathrm{p}<0.001)$.

Each unit increase of maternal education would increase current family 
income by 0.09 units $(b=0.09 ; \mathrm{SE}=0.49$; $\mathrm{p}=0.076$ ).

Each unit increase of family income at pregnancy would increase current family income by 0.79 units $(b=0.79 ; \mathrm{SE}=0.05$; $\mathrm{p}<0.001$ ).

Each unit increase of current family income would reduce maternal stress by 0.17 units $(b=0.17 ; \mathrm{SE}=0.09 ; \mathrm{p}=0.047)$.

Each unit increase of maternal stress would reduce democratic parenting by 0.59 units $(b=0.59 ; \mathrm{SE}=0.05 ; \mathrm{p}<0.001)$.

Each unit increase of maternal education would increase democratic parenting by 0.13 units $(\mathrm{b}=0.13 ; \mathrm{SE}=0.39 ; \mathrm{p}=$ 0.054).

Each unit increase of maternal education would reduce permissive parenting by 0.27 units $(b=0.27 ; \mathrm{SE}=0.26 ; \mathrm{p}=0.002)$.

Each unit increase of current family income would increase permissive parenting by 0.20 units $(\mathrm{b}=0.20 ; \mathrm{SE}=0.03 ; \mathrm{p}=$ o.018).

Each unit increase of democratic parenting would reduce permissive parenting by 0.27 units $(b=0.27 ; \mathrm{SE}=0.04 ; \mathrm{p}$ $<0.001)$.

Each unit increase of maternal education would increase body length at birthby 0.18 units $(b=0.18 ; \mathrm{SE}=0.43 ; \mathrm{p}=0.031)$.

Each unit increase of body length at birth would increase birth weight by 0.51 units $(\mathrm{b}=0.51 ; \mathrm{SE}=0.18 ; \mathrm{p}<0.001)$.

Each unit increase of family income at pregnancy would reduce birth weight by 0.15 units $(b=0.15 ; \mathrm{SE}=0.09 ; \mathrm{p}=0.034)$.

Each unit increase of maternal stress would increase authoritarian parenting by 0.21 units $(b=0.21 ; \mathrm{SE}=0.03 ; \mathrm{p}<0.001)$.

Each unit increase of maternal education would reduce authoritarian parenting by 0.08 units $(\mathrm{b}=0.08$; $\mathrm{SE}=0.28 ; \mathrm{p}=$ 0.136).

Each unit increase of permissive parenting would increase authoritarian parenting by 0.16 units $(\mathrm{b}=0.16 ; \mathrm{SE}=$ 0.09; $\mathrm{p}=0.003$ ).

Each unit increase of democratic parenting would reduce authoritarian parenting by 0.58 units $(\mathrm{b}=0.58 ; \mathrm{SE}=$ 0.06 ; $\mathrm{p}<0.001$ ).

\section{DISCUSSIONS}

\section{The influence of maternal educa- tion on children's language deve- lopment}

There was a positive relationship between maternal education and children's language development. Maternal education would improve language development $(\mathrm{b}=0.85$; $\mathrm{SE}=0.31 ; \mathrm{p}=0.007$.

Higher maternal education will increase the use of democratic parenting in children which can directly improve child language development and reduce the use of authoritarian parenting which can directly reduce children's language development. Mothers with higher education try to find information in order to improve their knowledge and skills, especially in parenting. Parents with higher education tend to easily receive information and apply it in behavior change (Hastuti, 2010).

Low education is thought to be linearly related to the lack of knowledge and skills of the mother (Dharmayanti et al., 2015). Maternal education has a role in children development because education can create a positive attitude for mothers so that it can stimulate an increase in language development in pre-school children, especially children less than 3 (three) years (Hidayat, 2005). Stimulation of children development with various therapies must also be given to children who experience language delays (Santrock, 2012).

An overview of the educational background of the mother as a study subject showed that most mothers are highly educated. A good level of maternal education 
increases the ability to absorb information about language development in children. This information can be obtained from the mass media, information from trusted people (family, relatives and others) and health workers. The results of the study showed that there was a positive and significant influence between the level of maternal education and family income on language development in children. The level of education influences one's work. Higher level of education causes a person to get a higher income than the regional minimum wage. On the contrary, the lower the level of education, the ability to find jobs to get higher income than the regional minimum wage is difficult or not easy (Hastuti, 2010).

The income received by the family is influenced by the level of education. Higher education causes families to get wider opportunities to get better jobs and higher income. Families with higher income have a high awareness of health efforts. The level of family income that is less than the regioinal minimum wage affects family awareness to make prevention efforts (Maidartati and Persaulian, 2015).

The results of this study are consistent with the study conducted by Dharmayanti et al. (2015) which stated that households with high socio-economic status, in terms of education, income and occupation, have higher economic capacity to maintain the health condition of their families and will strive so that his family can live a healthy life. High educational attainment increases family income and productivity. Education is the path to progress and achievement of family social and economic welfare (Thakur et al., 2013). So, it can be concluded that the results of this study are in accordance with previous studies because maternal education affects language development in children.

\section{The ifluence of body length at birth and body weight on children's language development}

Normal birth weight improve children's language development $(\mathrm{b}=0.07)$. Baby size consists of body weight and body length. The average weight of a baby at birth is between 3,000 g to 4,000 g. However, there are some babies born below or exceeding the average. Child's birth weight is classified as low birth weight (LBW) if the body weight is under 2,500 grams. Normal birth weight (NBW) is when a baby is born with a weight above 2,500 grams to 4,000 grams. High birth weight (HBW) is when the weight is above 4,00o grams. The normal birth length of a child is body length $\geq 48 \mathrm{~cm}$ (Soetjiningasih, 2012).

In the first week of birth, babies experience weight loss. Premature babies have difficulty adapting to the environment at the time of adulthood (Hurlock, 1978). The newborn's body length affects the baby's body size which then affects the baby's birth weight (Morgan et al., 2016).

Birth weight influences directly on language development. Normal birth weight improves children's language development $(b=0.07)$. The results of this study are in accordance with previous studies conducted by Verkasalo et al., (2004) which stated that preterm infants with very low birth weight would have lower language comprehension scores at 2 years and have difficulties in language comprehension, name mentioning, and auditory perception discrimination at 4 years compared to babies with normal birth weight.

\section{The influence of parenting style on children's language development}

The first three years of life is a critical period in early language development and concentration of attention due to increased brain synapse density during childhood and it reaches the maximum at 1-2 years 
(Hutten-locher, 1979). Hence, parenting at this stage greatly determines the child's development in the future. Parenting is all activities carried out as an effort to increase physical and brain growth (Musaheri, 2007).

The pattern of parenting consists of authoritarian, permissive and democratic parenting. Parenting has a contribution to children's development. Differences in parenting also have different developmental outcomes for each child. These three patterns will affect children's development. Liet al. (2013) stated that good parenting in the first three years of life affects memory, cognitive and language development in children. Mothers who can always provide time for their children can pay attention to each child's growth and can choose flexible ways of nurturing in accordance with the child's development stage, character, and situation at hand (Lestari, 2012).

Children who are raised with permissive parenting tend to be less responsible, have poor emotional control, and lower achievement. Children who are raised with democratic parenting will have better personal and social adjustment, be more independent and responsible (Soetjiningsih, 2012).

The results showed that parents with high democratic parenting improved language development $(b=0.58)$. Parents who apply high authoritarian parenting can reduce language development $(b=-0.51)$. Parents with high permissive parenting can improve children's language development $(b=0.26)$. The results of this study are supported by the study of Pong and Johnston (2010) which stated that children who are raised with democratic parenting showed higher psychosocial, social development, self perception, and mental health compared to children raised with permissive and authoritarian parenting. Children who are raised by permissive parents tend to lose their sense of responsibility, poor emotional control, and poor achievement. Children who are raised by democratic parents have better personal and social adjustments so that parents provide opportunities for children to be able to optimize their development. Democratic parents can provide a comfortable environment for children so it will affect the development of a better language (Hurlock, 1978).

Higher maternal education reduce the use of permissive parenting, increase the use of democratic parenting, and reduce the use of permissive parenting. Rahayu et al. (2003) stated that there was an influence between parenting and child development. Mothers who can always provide free time for their children can pay attention to each child's growth and can choose flexible ways of nurturing in accordance with the child's development stage, child's character, and situation (Lestari, 2012).

\section{The influence of family income at pregnancy on children's language development}

Income is an addition of economic capability received or obtained by taxpayers from both Indonesia and outside that can be used for consumption or to increase the taxpayer's wealth, with any name and form (Law No. 17/2000).

Family income at pregnancy and current family income indirectly affect children's language development through birth weight. The higher is the family income, the easier it is to meet daily needs and other needs. Conversely, the lower is the family income, the more difficult it is for the family to meet their daily needs and other needs. Income will affect a person's social status, especially in materialist and traditional societies that value high socioeconomic status that will affect children. Income in the family also contributes to the 
development of children. Families with sufficient income allow parents to provide game equipment as the means of stimulating child development. The family also tends to provide an environment that indirectly causes children to interact so that developmental stimulation occurs both physically and verbally (Freitas, 2013; Martini, 2012; Hastuti, 2009).

Family income now interacts synergistically with aspects of the family as well as outside the family, especially in this case is the selection of daycare centers (Brady et al., 2001). Households with high socioeconomic status have higher economic capacity to maintain the health condition of their families and can strive for his family to live a healthy life. Low socio-economic parents are unable to provide basic needs for children which can stimulate child growth optimally (Soetjiningsih, 2012). A study conducted by Ellingsen et al., (2014) suggested that socio-economic status had an effect on health status. Poor economic status will affect health in the future.

Higher maternal education will increase family income at pregnancy and current family income. The increase in education will affect the opportunity to get a better job so that it can increase family income both at pregnancy and current income. Low education and income are the cause of lack of food availability in the family, one of which is the availability of healthy and nutritious foods that can affect the growth and development of children since in the womb until adulthood (Mohd et al., 2015).

Current family income that is getting higher will increase the use of permissive parenting. With high income parents will meet the needs of children. This is slightly different from the study conducted by Anton et al. (2015) which stated that there was an influence of family income on parenting style. Higher family income increases the use of democratic parenting and decreases permissive parenting.

\section{The influence of maternal stress on children's language develop- ment}

There is a direct influence between maternal stress and children's language development. High maternal stress can reduce children's language development $(b=0.09)$. Parental stress can affect the use of parenting. Parents with severe stress levels increase the use of authoritarian parenting to children which causes a decline in language development. This is consistent with the study of Smith et al. (2011), which stated that stress in parents can affect children's speech. Parents with mild stress who train children to speak have a positive impact on children's language development.

Monk et al. (2012) stated that severe psychological stress increases the risk of prematurity, low birth weight, inhibition of neuronal and cognitive development in children, hyperactivity disorder, and other mental health disorder.

A study from Dunkel and Tanner (2012) suggested that mothers who experience various physical or psychological stresses are caused by various factors and one of them is mother's bad experience before pregnant. Effects of pregnancy that have an impact on life, especially if the mother is a career woman is the anxiety about being a mother, financial and household matters, acceptance of pregnancy by others, and discomfort during pregnancy such as nausea, fatigue, and changes in appetite. This condition triggers an increase in hormone cortisol and stimulates the hormone prostaglandin for the uterus to contract prematurely which causes blood vessels to constrict so that the fetus experiences a deficiency of nutrients through 
the placenta and has the potential to give birth a baby with low birth weigt.

Based on the results of the study, it can be concluded that language development is directly influenced by democratic parenting, birth weight, authoritarian parenting, maternal education, permissive parenting, and maternal stress. Democratic parenting is influenced by maternal stress and maternal education. Birth weight is influenced by body length at birth and family income at pregnancy. Body length at birth and family income at pregnancy are influenced by maternal education. Authoritarian parenting is influenced by maternal stress, maternal education, permissive parenting, and democratic parenting. Permissive is influenced by maternal education, current family income, and democratic parenting. Maternal stress is affected by current family income. Current family income is influenced by maternal education and family income at pregnancy.

\section{REFERENCE}

Anton MT, Deborah JJ, Eric AY (2015). Socioeconomic Status, Parenting, and Externalizing Problems in African American Single-Mother Homes: A Person-Oriented Approach. J Fam Psychol 29(3): 405-415.

Brady N, Skinner D, Roberts J, Hennon E (2006). Communication in young children with Fragile X syndrome: A qualitative study of mothers' perspectives. American Journal of SpeechLanguage Pathology 15: 353-364.

Dharmayanti I, Hapsari D, Azhar K (2015). Asthma among Children in Indonesia: Causes and Triggers. Jurnal Kesehatan Masyarakat Nasional 9(4):320326.

Dunkel SC, Tanner L (2012). Anxiety, Depression and Stress in Pregnancy: Implication for Mothers, Children,
Research, and Practice. Curr Opin Psychiatry 25:141-148.

Ellingsen R, Baker BL, Blacher J (2014). Resilient Parenting of Children at Developmental Risk Accross Middle Childhood. Res Dev Disabil 35(6): 1364-1374.

Freitas TC, Gabbard C, Cocola PP, Montebelo, Santos (2013).Family socioeconomic Status and the Provision of Affordances in the Home. Epub 17(4): 319-27.

Hastuti (2010). Nilai Anak, Stimulasi Psikososial, dan Perkembangan Kognitif Anak Usia 2-3 tahun pada Keluarga Rawan Pangan di Kabupaten Banjarnegara, Jawa Tengah. Institut Pertanian Bogor. Jurnal Ilmu Keluarga dan Konsumen 3(1): 21-34.

Hidajati Z (2009). Faktor Risiko Disfasia Perkembangan. Tesis Universitas Diponegoro.

Hurlock E (1978). Perkembangan Anak Jilid I. Jakarta: Penerbit Erlangga.

Huttenlocher PR (1979). Synaptic density in human frontal cortex-Developmental changes and effects of aging. Brain Research 163:195-205.

Lestari S (2012). Psikologi Keluarga Pananaman Nilai dan Penanganan Konflik dalam Keluarga.Jakarta: Kencana.

Li W, George Farkas, Greg J. Duncan, Margaret R. Burchinal, Deborah L V (2013). Timing of High-Quality Child Care and Cognitive, Language, and PreacademicDevelopment.Dev Psychol 49(8): 1440-1451.

Maidartati, Persaulian P (2015). Gambaran Penetahuan Ibu Hamil Trimester 1 tentang Pengaruh Rokok terhadap Tumbuh Kembang Janin di Poli Kandungan RSUD Kota Bandung. Jurnal Ilmu Keperawatan 3(1): 38-50.

Mcleod S, Harrison LJ (2009).Epidemiology of speech and language impairment in a nationally representative sample of 4 to 5year old children. 
Journal of speech, language, and hearing research 52:1213-1229.

Mohd SZ, Lin KG, Sariman S, Lee HS, Siew CY (2015). The relationship between household income and dietary intakes of 1-10 years old urban Malaysian. Nutrition Research and Practice 9(3): 278-287.

Morgan KL, Lyons RA, Khanom A, Brophy ST (2016). Cohort Profile: Growing Up in Wales: The Environments for Healthy Living study. International Journal of Epidemiology 45 (2).

Mueller KL, Murray JC, Michaelson JJ, Christiansen MH, Reilly S, Tomblin JB (2016). Common Genetic Variants in FOXP2 Are Not Associated with Individual Differences in Language Development. Plos One.

Murti B (2013). Desain dan Ukuran Sampel untuk Penelitian Kuantitatif dan Kualitatif di Bidang Kesehatan. Yogyakarta: Gadjah Mada University Press.

Murti B (2016). Prinsip dan Metode Riset Epidemiologi. Surakarta: Program Studi Ilmu Kesehatan Masyarakat Universitas Sebelas Maret.
Musaheri (2007). Pengantar Pendidikan. Yogyakarta: IRC iSoD.

Pong SL, Johnston J (2010). Authoritarian parenting and Asian adolescent school performance: Insights from the US and Taiwan. Int $J$ Behav Dev 34(1): 62-72.

Santrock (2012). Buku masa perkembangan anak. Jakarta: Salemba Medika.

Smith A, Romski MA, Sevcik RA, Adamson LB, Bakeman R (2011). Parent's stress and its relation to parent perceptions of communication following parentcoached language intervention.Journal of Early Intervention 33:135-150.

Soetjiningsih (2012). Tumbuh Kembang Anak. Jakarta : EGC.

Undang-Undang Republik Indonesia Nomor 17 tahun 2000 tentang Pajak dan Penghasilan.

Verkasalo J, Valkama M, Vainionpaa L, Paakko E, Ilkko E, Lehtihalmes M (2004). Language development in very low birth weight preterm children: A follow-up study. Folia Phoniatr Logop. 56:108-119. 